УАK 349.3

ББК 67.405 .2

DOI 10.22394/1682-2358-2018-6-44-50

V.V. Regalin, degree seeking applicant of the Legal Support of the Market Economy Department Russian Presidential Academy of National Economy and Public Administration

\section{CIVIL LEGAL \\ RELATIONS IN \\ THE FIELD OF \\ SANATORIUM-RESORT \\ ORGANIZATIONS SERVICES}

The civil law regulation of health resort services provision in modern conditions is analyzed. The contradictions of contractual relations are investigated. A number of gaps existing in the regulatory framework of health resort treatment legal regulation is highlighted. Measures to improve the legislation regulating the sphere of sanatorium and resort services are proposed.

Key words and word-combinations: civil legal relations, agreement, complex character, regulation, health resort services.
В.В. Регалин, соискатель кафедри правового обеспечения рогночной экономики Российской академии народного хозяйства и государственной служби при Президенте РФ (email: regalin_vv@mail.ru)

\section{ГРАЖКААНСКО-ПРАВОВЫЕ ОТНОШЕНИЯ В СФЕРЕ ОКАЗАНИЯ УСАУГ САНАТОРНО-КУРОРТНЫМИ ОРГАНИЗАЦИЯМИ}

Аннотация. Анализируется гражданско-правовое регулирование оказания санаторно-курортных услуг в современных условиях. Исследуются противоречия договорных отношений. Выделяется ряд пробелов, существующих в нормативной базе правового регулирования санаторно-курортного лечения. Предлагаются меры по совершенствованию законодательства, регулирующего сферу санаторно-курортных услуг.

Ключевые слова и словосочетания: гражданско-правовые отношения, договор, комплексный характер, регулирование, санаторно-курортные услуги.

$\mathrm{O}$ ЗАоровья гражАан в соответствии с российским законодательством признается приоритет профилактики в сфере охраны зАоровья. Разнообразие курортных и мечебных факторов Российской Федерации создает оздоровительную и реабилитационную базу Амя населения. Значимость развития санаторно-курортного комплекса России поА- 
черкивается перечнем поручений Президента РФ по итогам заседания Президиума Государственного совета РФ в 2016 г.

Ясность и оАнозначность толкования, единообразное применение основополагающих правовых понятий, относящихся к мечебно-оздоровительной сфере, является одним из важнейших императивов в системе гражданскоправового регулирования деятельности санаторно-курортных организаций. Понятия, закрепленные в законах и подзаконных нормативных правовых актах, не могут допускать смешения объекта и предмета гражданско-правового регулирования в цюбой сфере деятельности, в том числе и в системе зАравоохранения. При переходе от административно-правового к современному договорно-правовому регулированию санаторно-курортной деятельности в отечественном законодательстве оказалось множество пробелов, связанных с неполнотой, неупорядоченностью, противоречивостью системы гражданскоправовых понятий в исследуемой сфере деятельности.

Санаторно-курортные организаџии вынуждены в борьбе за потребитемя приспосабливаться к условиям, сложившимся в современном обшестве. Потребители заинтересованы в получении санаторно-курортной помощи без особых формальных проволочек, с высоким уровнем мечения, сервиса и проживания. ОАнако системы, по которой можно было бы оџенить качество мечения санаторно-курортных организаџий, например, как пятизвездочная система гостиниц, не существует. Аобровольная сертификаџия услуг санаторно-курортных организаџий тоже отсутствует.

В современных программах реформирования санаторно-курортных услуг не выработаны планы нормативного усовершенствования санаторно-курортной сферы; не опредемены юридические положения оказания санаторнокурортных услуг; не разработаны правовые гарантии развития курортного дема; не сформирован механизм объединения всего многообразия субъектов санаторно-курортного комплекса Российской Федераџии; не созданы предпосылки развития посещения иностранцами российских санаторно-курортных организаџий. Следовательно, отсутствует комплексный подход к реформированию данной соџиальной сферы.

Некоторые иссиедователи подчеркивают необходимость создания системы управления санаторно-курортным комплексом, что, на наш взгляА, в сложившихся рыночных отношениях нещелесообразно. Выработка общей политики развития Аанной отрасли входит в функџии государства, а государственное управление всем многообразием санаторно-курортных организаций различных организационно-правовых форм собственности неоправданно экономически и не отвечает реалиям развития рыночных отношений.

В отечественном гражданском законодательстве отсутствует определение понятий «санаторно-курортная организация», «санаторно-курортная деятельность», «комплекс санаторно-курортных услуг». В гражданском праве поА санаторно-курортной организацией подразумевается «мечебное учреждение, которое осуществляет медиџинскую помощь в профилактических, мечебных и реабилитационных цемях на основе использования природных мечебных ресурсов, в том числе в условиях пребывания в мечебно-оздоровительных местностях и на курортах» [1] . 
Аналогом понятия «санаторно-курортная услуга», свойственного российскому праву, в современной межАународной практике мечебно-оздоровительного туризма является услуга, предоставляемая в рамках sра-индустрии. По определению Всемирной туристской организации (IUOTO), преАложенному в 1973 г., ее в равной степени можно отнести как к услуге, оказываемой организаџиями sра-индустрии, так и к ускуге в рамках санаторно-курортного мечения.

В понятие «санаторно-курортное иечение» законодатель включает «медицинскую помощь, осуществляемую медицинскими организациями (санаторно-курортными организациями) в профилактических, мечебных и реабилитационных целях на основе использования природных цечебных ресурсов, в том числе в условиях пребывания в мечебно-оздоровительных местностях и на курортах» [2]. Аанный виА мечения направлен на формирование целого ряда условий оздоровления: активацию защитно-приспособительных реакщий организма в цемях профикактики заболеваний, оздоровления, а также восстановление и (ими) компенсацию функций организма, нарушенных вследствие травм, операций и хронических заболеваний, уменьшение количества обострений, удлинение периода ремиссии, замедление развития заболеваний и предупрежАение инвалидности в качестве одного из этапов медицинской реабилитации.

Исследователи при определении вида правоотношений, скмадывающихся в санаторно-курортной сфере, придают большое значение такой характеристике договора, как цель его заключения. В советский период основная цель посещения санаторно-курортных учреждений состояла в поддержании и восстановлении здоровья. С тенденцией перехода от санаторно-курортной системы к курортно-рекреационной названная цель становится не еАинственной. Пациенты посещают санаторно-курортные организации с целью отдыха, а иногда и познавательно-развлекательной.

В договоре об оказании мечения основной целью соглашения должно стать следующее: поддержание и восстановление здоровья, что связано с повышением функциональных резервов организма, активацией защитно-приспособительных реакций, направленной на первичную профилактику заболеваний; восстановмение и компенсация функций организма, нарушенных в связи с последствиями травм, операџий и хронических заболеваний; уменьшение количества обострений; удлинение периода ремиссии; замедление прогрессирования заболеваний. Аля отдыхающих целью договора оказания предоставляемых услуг является отдых в опредеменной местности, где созданы соответствующие условия проживания, питания, развлечений. Во время оказания услуг отдыхающий получает информацию, касающуюся предупреждения нарушений зАоровья.

Современными исследователями ведутся научные дискуссии об отнесении правоотношений в санаторно-курортной сфере к услугам или к работам (подряду). В теории гражАанского права существует Ава прямо противопоможных мнения о том, что «услуга» - разновидность «работы» и «работа» это вид «ускуг» [3, с. 209]. Аействуюшее отечественное законодательство не

46 Bulletin of the Volga Region Institute of Administration • 2018. Vol. 18. № 6 
содержит определения термина «услуги». Законодатель сформулировал модель Аоговора подряда в главе 37 ГК РФ и договора о возмездном оказании услуг в главе 39 ГК РФ.

По Аоговору об оказании услуг исполнитель за определенную плату обязуется по заданию заказчика оказать услуги, совершив определенные действия или определенную Аеятельность. При сравнении Авух моделей видно, что предмет подряда составцяет действие (работа) и его результат, а возмезАного оказания услуг - только действия как таковые. Учеными выделяется специфичный признак договора услуг - его предмет. Это «непередаваемое, неразрывно связанное с деятельностью благо», «неовеществленный результат», неотАелимый от исполнения услуги результат или полезный эффект. В научной мысли отсутствие овеществленного результата как основной признак услуги и отграничения от понятия работ приобрело наибольшую подАержкку.

Большинство исследователей отмечают комплексной характер санаторнокурортной услуги, вкцючающей в себя такие понятия, как «лечение», «питание», «проживание» [4, с. 25]. Аоговор на оказание санаторно-курортных услуг вкцючает в себя признаки как договора возмездного оказания услуг (медицинских и гостиничных), так и Аоговора подряда при оказании услуг питания.

Ученые выдемяют смешанный вид Аоговора, если договор по оказанию медиџинских услуг, целью которого является подАержание и восстановление зАоровья, содержит обязанности исполнителя, не связанные с Аанной целью. В этом случае предметы договора подлежкат разному правовому регулированию. По определению В.А. Ойгензихта, если в результате осуществления разцичных действий есть вещественный результат, а действия составцяют опредеменное единство, то это не явцяется смешанным договором оказания услуг и Аоговором подряда и целесообразнее использовать термин «нетипичный» [5, с. 4]. ОАнако в современном мире использование данного термина противоречит реацьности, поскольку самыми распространенными договорами явцяются смешанные, то есть с разцичными элементами Аругих договоров (п. 3 ст. 421 ГК РФ).

По замечанию С.С. Шевчука, «в Гражданском колексе Российской Федерации, с одной стороны, допускается смешение договоров по оказанию услуг и Аоговоров подрядного типа, а с Аругой - отграничиваются Аоговоры оказания услуг от подрядных Аоговоров, и Аоговоры на выполнение работ относятся к Аоговорам об оказании услуг» [6, с. 132]. А.А. Сироткина предиагает «Аифференцировать работы и услуги в зависимости от наличия возможности разАелить процесс оказания медиџинской услуги на отдельные этапы без ущерба Аля целостности каждого из них» [7, с. 14] .

Согласно кмассификации А.Б. Ситдиковой выдемяются «чистые услуги», отмичительной чертой которых является отсутствие вещественного результата, а также «дополнительные, вспомогательные» услуги» [8, с. 93] . К «вспомогательным» медицинским услугам относятся транспортировка пациента, медицинские процедуры, выполняемые по назначению врача. М.Н. Шияпникова и А.И. Казначеев предкагают «кцассифицировать курортные ускуги 
по Авум основаниям - мечебно-оздоровительные и рекреационно-досуговые» $[9$, с. 12].

В действительности санаторно-курортная организация не только оказывает медицинские услуги, но и предоставцяет питание, размешение, транспортировку. Предмет правового регулирования разцичен. Услуги питания и предоставление проживания имеют неодинаковый результат. Результат реабилитации и санаторно-курортного мечения нельзя преАставить без учета усмовий проживания, влияния природных факторов, мечебного питания, уровня обслуживания. Все организации, имеющие миџензию на осуществление меАиџинской деятельности в условиях пребывания в мечебно-оздоровительных местностях и на курортах, обязательной первоочередной целью пребывания в данных местностях имеют мечение или реабилитацию. В том случае, если в Аоговоре указаны и медицинские услуги, и сопутствующие, то договор явцяется смешанным.

В настоящее время договор явцяется универсальной правовой формой Амя взаимоотношений субъектов в проџессе осуществления предпринимательской Аеятельности. В ГК РФ представлено правовое регулирование Аоговора на оказание услуг. При этом Аоговор на оказание медицинских услуг, в частности санаторно-курортных услуг, не выделен в самостоятельный виА договора. Основы российского законодательства об охране здоровья граждан носят скорее декларативный характер и не содержат нормы, четко регулирующие поряАок заключения, прекращения или изменения правоотношений по оказанию санаторно-курортных услуг, что приводит к созданию проблем толкования Аоговора оказания санаторно-курортных услуг, к самостоятельному определению сторонами условий заключения договора.

Отличительный признак Аоговора оказания санаторно-курортных услуг связан с его сложным, комбинированным, комплексным, консенсуальным, взаимным, возмездным характером, наличием письменного согласия при оказании санаторно-курортной услуги. В обязательстве об оказании санаторнокурортных услуг могут содержаться несколько обязанностей: санаторно-курортная помощь, предоставление помещения Аля временного проживания, обеспечение питания, иные гостиничные и досуговые услуги.

Таким образом, санаторно-курортная услуга отличается комплексным характером, обладает рядом специфических особенностей гражАанско-правового регулирования профилактической и реабилитационной деятельности санаториев. Санаторно-курортная услуга вкцючает в себя медицинские, Аиагностические, консультационные услуги, а также услуги, связанные с предоставлением помещения Аля временного проживания, транспортным обслуживанием, питанием, Аосуговым, туристическим, спортивным, культурным и Аругими видами времяпрепровождения.

Услуги, оказываемые санаторно-курортными организациями, Аолжны в обязательном порядке сертифицироваться и миџензироваться. Аля повышения качества оказания санаторно-курортных услуг в современных условиях необходимо предложить и сформировать систему иицензирования и сертификации услуг санаторно-курортных и оздоровительных организаций. Аанная 
система мицензирования должна включать комплексную оценку соответствия санаторно-курортного мечения, проживания и питания, а также организации Аосуговой деятельности.

Аействующая система добровоцьной сертификации услуг санаторно-курортного мечения проводит оценку их соответствия установценным нормативам, однако она не оценивает систему питания и проживания. Например, санаторий Аця пожицого человека преАставляет эффективное медицинское обслуживание, но проживание в многоместном номере на пятом этажке без цифта может его Аезориентировать.

Аля подтверждения соответствия проживания санаторно-курортная ици оздоровительная организаџия Аолжна пройти сертификацию по стандарту «Система добровольной сертификации услуг гостиниџ и других средств размещения на категорию» или «Туристские услуги. Средства размещения. Общие требования. ГОСТ Р 51185-2008». Стандарт содержкит общие требования к средствам размещения и предоставлению услуг. Аця подтверждения соответствия питания установленным стандартам санаторно-курортная организация Аолжна пройти сертификаџию по «ГОСТ Р 50762-2007. Наџионацьный станАарт Российской Федерации. Услуги общественного питания. Классификация преАприятий общественного питания» .

Проведенный анализ действующего российского законодательства об охране здоровья граждан показывает, что санаторно-курортная сфера требует законодательного совершенствования по следующим направлениям: во-первых, урегулирование правовых отношений санаторно-курортных преАприятий с потребителями, в том числе зарубежными; во-вторых, определение компетенции органов исполнительной власти всех уровней; в-третьих, разработка стандартов санаторно-курортного мечения.

Согласно федеральному законодательству об охране здоровья граждан общее требование к качеству медицинских услуг обеспечивается соблюдением поряАков и стандартов оказания медицинской помощи. Требования государственных стандартов относятся главным образом к безопасности услуг. ОАнако паџиент не имеет специальных познаний в медицине и можкет не знать, что имеются соответствующие требования к качеству медицинских услуг. Следовательно, в Аоговоре необходимо указать конкретный порядок и стандарт санаторно-курортной помощи, которому должна соответствовать медиџинская услуга.

В Аоговоре оказания определенного вида медиџинской помощи слеАует указывать установленный стандарт, в соответствии с которым она осуществляется. ВкАючение стандарта в Аоговор позволит потребителю указать те мероприятия, от которых он намерен отказаться, или дополнить отдельными медицинскими услугами. Так как терапия имеет выражкенные последствия, необходимо учитывать результаты санаторно-курортного мечения в Аальнейшем (через месяц, гоА).

Поскольку качество явцяется оџеночным показателем самого пациента, необходимо рассматривать его удовлетворенность услугой. Изучение удовлетворенности паџиентов санаторно-курортными услугами единичны, а критерии оценки часто не имеют научного обоснования. В настоящее время разработаны 
организационные модели системы управления удовлетворенностью пациентов медиџинской реабилитацией в санаторно-курортных условиях, позволяющие выяснить степень удовлетворенности пациентов качеством полученных услуг.

Аля реализации указанных направлений совершенствования законодательства, регулирующего сферу санаторно-курортных услуг, по нашему мнению, необходимо внести в Федеральный закон «Об основах охраны здоровья гражАан Российской Федерации» отдельную главу, регулирующую особенности правоотношений в санаторно-курортной сфере; упорядочить нормативноправовую базу; устранить имеющиеся противоречия с детальной проработкой и распределением полномочий по уровням управления.

В приказ Министерства здравоохранения и соџиального развития Российской Федерации «О порядке медицинского отбора и направления на санаторнокурортное мечение» уместно внести определенные дополнения, обозначив несколько вариантов отбора пациентов и направления их на санаторно-курортное мечение. ОАним из основных условий заключения Аоговора оказания санаторно-курортной помощи может стать предоставление паџиентами выписки из амбуматорной карты взамен санаторно-курортной карты. Необходимые Аля назначения эффективного мечения обследования целесообразнее провоАить непосредственно в оздоровительной организаџии переА подписанием Аоговора на оказание санаторно-курортной помощи.

При заключении договора возмезАного оказания медицинских услуг необходимо понимать, что оказываемые услуги домжны соответствовать требованиям, предъявмяемым к профилактическим и цечебным методам. Выделение Аоговора на оказание медиџинских услуг в отдельную главу, включающую нормы, регулирующие оказание санаторно-курортной помощи, желательно в качестве меры по совершенствованию российского законодательства об охране зАоровья гражАан.

\section{Библиографический список}

1. Об утверждении Порядка организации санаторно-курортного лечения: приказ Министерства здравоохранения РФ от 5 мая 2016 г. № 279н. URL: http://www.garant.ru/products/ipo/ prime/doc/71327710/\#ixzz5dDplK7Nw

2. Об основах охраны здоровья граждан в Российской Федерации: Федер. закон от 21 нояб. 2011 г. № 323-Ф3 // Российская газета. 2011 г. 3 нояб.

3. Брагинский М.И., Витрянский В.В. Договорное право. М., 2003.

4. Нуждин Т.A. Договор на оказание санаторно-курортных услуг в системе гражданского законодательства Российской Федерации // Право и экономика. 2009. № 1.

5. Ойгензихт B.A. Нетипичные договорные отношения в гражданском праве: учебное пособие. Душанбе, 1984.

6. Шевчук С.С. Личные неимущественные права граждан в сфере медицинских услуг по гражданскому законодательству России: дис. ... д-ра юрид. наук. Ростов н/Д, 2005.

7. Сироткина A.A. Договор оказания медицинских услуг: особенности правового регулирования. М., 2004.

8. Ситдикова Л.Б. Правовое регулирование отношений по возмездному оказанию услуг: дис. ... канд. юрид. наук. Казань, 2002.

9. Шляпникова М.Н., Казначеев Д.И. Тенденции соотношения медицинских и немедицинских услуг в курортном регионе // Социология медицины. 2006. № 1. 